\title{
BEHAVIOUR OF SYNOVIAL FLUID ON SURFACES OF ARTICULAR CARTILAGE* A SCANNING ELECTRON MICROSCOPE STUDY
}

\author{
BY \\ P. S. WALKER ${ }^{1}$, J. SIKORSKI ${ }^{2}$, D. DOWSON 3 , M. D. LONGFIELD ${ }^{4}$, \\ V. WRIGHT ${ }^{5}$, AND T. BUCKLEY ${ }^{6}$ \\ Bioengineering Group on Human Joints, Rheumatism Research Unit, Department of Medicine, General Infirmary \\ at Leeds; Institute of Tribology, Department of Mechanical Engineering; and \\ Textile Physics Department, University of Leeds
}

Much attention has been given to the mechanics of synovial joints from a descriptive aspect and to studies relating to joint lubrication. The synovial fluid has been analysed and details of its composition are known (Ropes and Bauer, 1953). The principal constituent is hyaluronic acid-protein complex, the acid molecule having been shown to be a non-branched chain of repeating units with hydroxyl end-groups on each unit (Meyer, 1931). The acid-protein complex is responsible for the viscous properties of the synovial fluid (Negami, 1964; Davies, 1966) and it is fairly certain that it plays an important function in protecting the cartilage surfaces. A reasonably good picture has been obtained of the structure of articular cartilage, which is understood to consist of bundles of collagen fibres in a ground substance, chondroitin sulphate, with a high water content. The collagen bundles on the surface are believed to lie parallel to it. Those below are randomly or perpendicularly orientated to the surface depending upon the age and condition of the cartilage. (Benninghoff, 1930; Martin, 1953; Little, Pimm, and Trueta, 1958.)

The remarkable lubrication characteristics of joints have been found to be due to the combination of properties of synovial fluid and articular cartilage. From experiments using a reciprocating friction machine and by measuring the topography of the surfaces of cartilage with stylus equipment, it has been concluded that the cartilage surfaces are prevented from contacting primarily because of the formation of trapped pools of lubricant (Dowson, Longfield, Walker, and Wright, 1969). Furthermore, it has been shown that, under some conditions,

* The substance of this paper was given to the Heberden Society on November 23, 1968.

1 Research Fellow.

Senior Lecturer in Textile Physics.

Professor of Tribology and Fluid Mechanics.

- Manager, Industrial Unit of Tribology.

- Senior Lecturer, Consultant, and Physician in Rheumatology.

- Senior Electronics Engineer. fluid compressed between cartilage surfaces becomes concentrated in acid-protein complex to form a protective gel (Maroudas, 1967). This combination of trapped pools and fluid enrichment has been termed "boosted lubrication" (Walker, Dowson, Longfield, and Wright, 1968).

However, little has been reported about the surface of articular cartilage, or about the molecular aggregates of the acid-protein complex within the synovial fluid. The recent introduction of the scanning electron microscope makes such studies feasible and this paper reports various results obtained using this instrument.

High resolution electron micrographs of dried synovial fluid are shown, which give evidence of the configurations formed by aggregates of acidprotein complex molecules. On cartilage surfaces, bundles of collagen fibres of both large and small dimensions are seen.

In order to obtain corroborative evidence for lubrication by trapped pools, specimens of cartilage under compression were prepared. The resulting surfaces show localized areas of deposits which appear to be derived from synovial fluid, which has filled cavities between compressed cartilage surfaces. Finally, some photographs of osteoarthrosic cartilage are shown which suggest how degeneration by wear might proceed.

\section{Material and Methods}

The SI system of units are used

$$
\begin{aligned}
& 1 \mathrm{~nm} .=10^{-9} \mathrm{~m} .=10 \AA \\
& 1 \mu \mathrm{m} .=10^{-6} \mathrm{~m} .=1 \text { micron }
\end{aligned}
$$

\section{(1) The Scanning Electron Microscope}

In the scanning electron microscope, a beam of electrons is directed at the specimen and both reflected and secondary electrons are collected, the signal is amplified, and then rransformed into a picture on the 
screen. Two features of the instrument are particularly noteworthy: the high resolution and the extremely large depth of focus. Because of the second feature, the specimen can be tilted so that the incident angle of "illumination" can be varied.

Before being inserted into the instrument, specimens were dried and coated with a uniform layer of silver to provide a conducting layer for the impinging electron beam. The silver coatings were of the order of $10 \mathrm{~nm}$. thick, which does not significantly obscure details greater in size than about $2 \mathrm{~nm}$. (Tolansky, 1954), well within the resolving power of the instrument which is around $50 \mathrm{~nm}$.

\section{(2) Articular Cartilage}

The specimens were prepared with the object of preserving their structure when in the living joint. Pieces of cartilage were cut from femoral condyles or femoral heads post mortem, usually within 12 hours of death. Care was taken to ensure that they were un- contaminated with blood or other extraneous matter. The specimens, cut to about $4 \times 4 \times 1 \mathrm{~mm}$. thick, were then fixed, two methods being employed: osmium tetroxide and freeze drying.

In the first method, the fresh specimens were immersed in a solution of osmium tetroxide for about 24 hours at $\stackrel{O}{\sim}$ room temperature, then immersed in absolute alcohol 0 solutions of increasing concentration, and finally dried in air. An overall linear contraction of about 10 per cent. was observed after the drying and a slight curling of the edges took place.

Freeze drying involved a simpler procedure. The \& specimens were immersed in liquid nitrogen for about $\overrightarrow{0}$ 15 seconds and placed into the freeze drier. After 10. hours, dehydration was complete and the specimens were ready for silvering.

\section{(3) Synovial Fluid}

Specimens of synovial fluid were usually taken when $\underset{\infty}{\text { N }}$ joints of post mortem subjects were opened to obtain

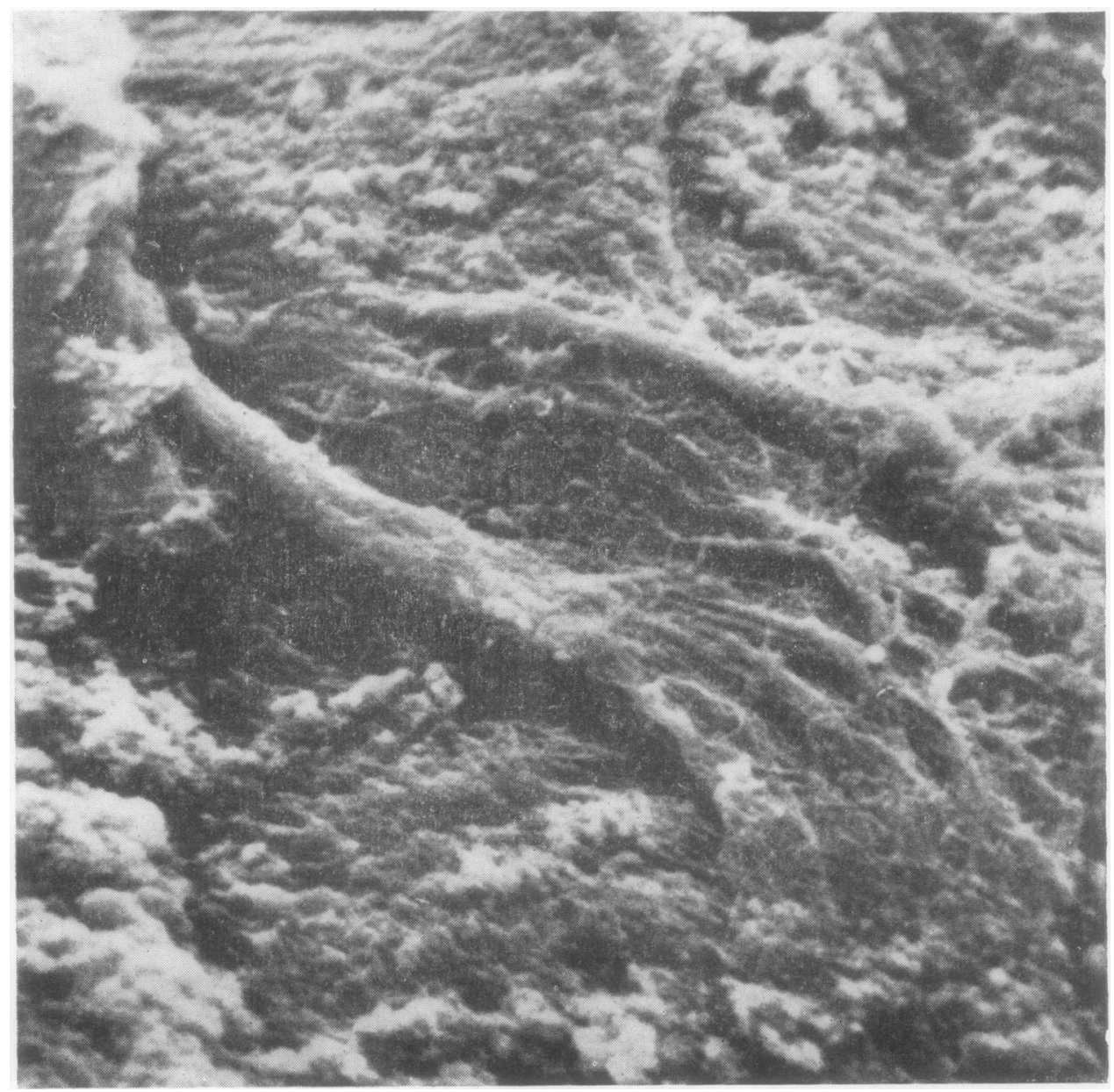

Fig. 1. - Surface of articular cartilage. $\times 4,530$. All electromicrographs with tilt angle (nominal) $0^{\circ}$, and $20 \mathrm{kv}$ accelerating potential. 
cartilage. The fluid, drawn off using a sterile syringe and needle, was stored at $2^{\circ} \mathrm{C}$. for only a short time before preparation for the electron microscope. The methods of fixation were the same as those used for cartilage with the addition of a third method, simply allowing the fluid to dry in air.

\section{(4) Cartilage Surfaces under Load}

Experiments were performed to simulate a load-bearing state when cartilage is pressed upon cartilage with synovial fluid interposed. A number of specimens were prepared by putting a drop of synovial fluid on a glass plate. A small specimen of cartilage was placed over the fluid and then surrounded with osmium tetroxide solution. A second piece of glass was laid on top of the cartilage, loading it to give the required pressure. The disadvantage of this method was that it took several hours for cartilage fixation, whereas in the physiological condition the joint surfaces are under static compression for much shorter durations.

The other fixation method, that of freeze drying, probably simulated the physiological condition much better. Apparatus was constructed where pieces of cartilage could be loaded against a glass plate or, alternatively, where two pieces of cartilage could be loaded on top of each other. Specimens were prepared by placing them on to synovial fluid and applying a load, and after a required time interval, which might only be one or two seconds, immersing the apparatus in liquid nitrogen. The loads were removed so that the specimens would not be subjected to compressive stresses which might damage them during the freeze drying process. It was found that, when dried, the specimens had adhered neither to the glass nor to each other.

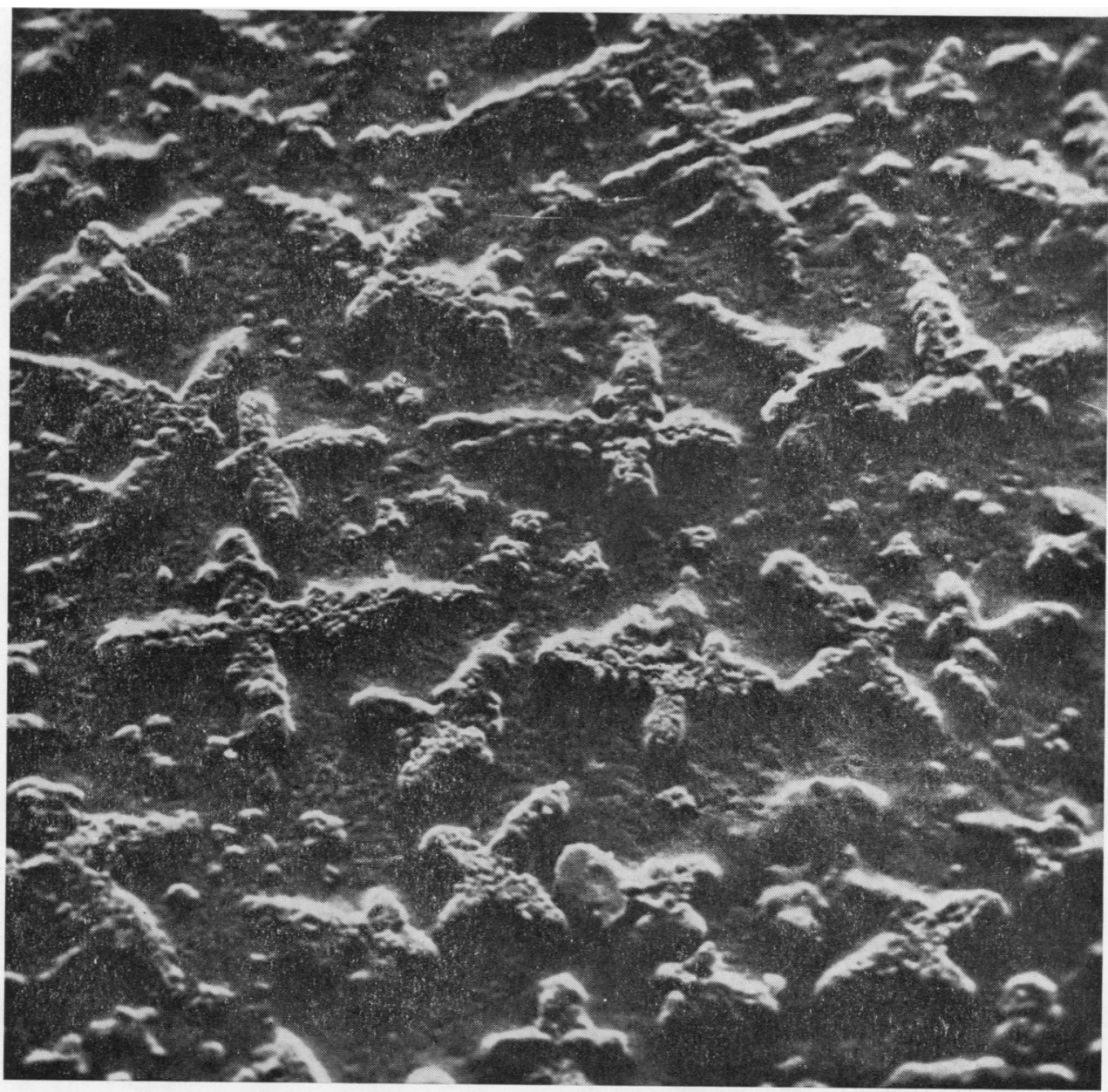

Fig. 2.-Synovial fluid, dried in air. $\times 145$. 


\section{Results}

\section{(1) Surface Structure of Articular Cartilage}

In the introduction, references were given to work which showed that bundles of collagen fibres at the surface of healthy articular cartilage lay parallel to it. This conclusion is consistent with the observation that thin strips can be readily peeled from the surface of healthy cartilage (Meyer, 1931).

In our studies, the surface appeared to comprise a network of fibre bundles, presumably of collagen, cemented together by the ground substance, chondroitin sulphate. There was one quite distinctive type of fibre bundle of significantly larger dimensions than most, their diameter ranging from 1 to $3 \mu \mathrm{m}$. They tended to lie along the surface for some distance and then at one or both ends, fanned out into a multitude of smaller fibre bundles. Many of the smaller bundles were thus seen to originate directly from the larger ones. In Fig. 1 (p. 2) all the features mentioned above can be seen. The ground substance has been removed, exposing the fibres very clearly.

In one case, where a large bundle was raised up from the surface slightly, a system of "roots" along its length was seen to go down into the underlying cartilage. These roots would probably hold the bundle firmly to the surface.

The spacing of the large bundles was in the range $10-50 \mu \mathrm{m}$. about the same distance as the pitch of the surface irregularities which have been measured by stylus tracing techniques (Walker and others, 1968).

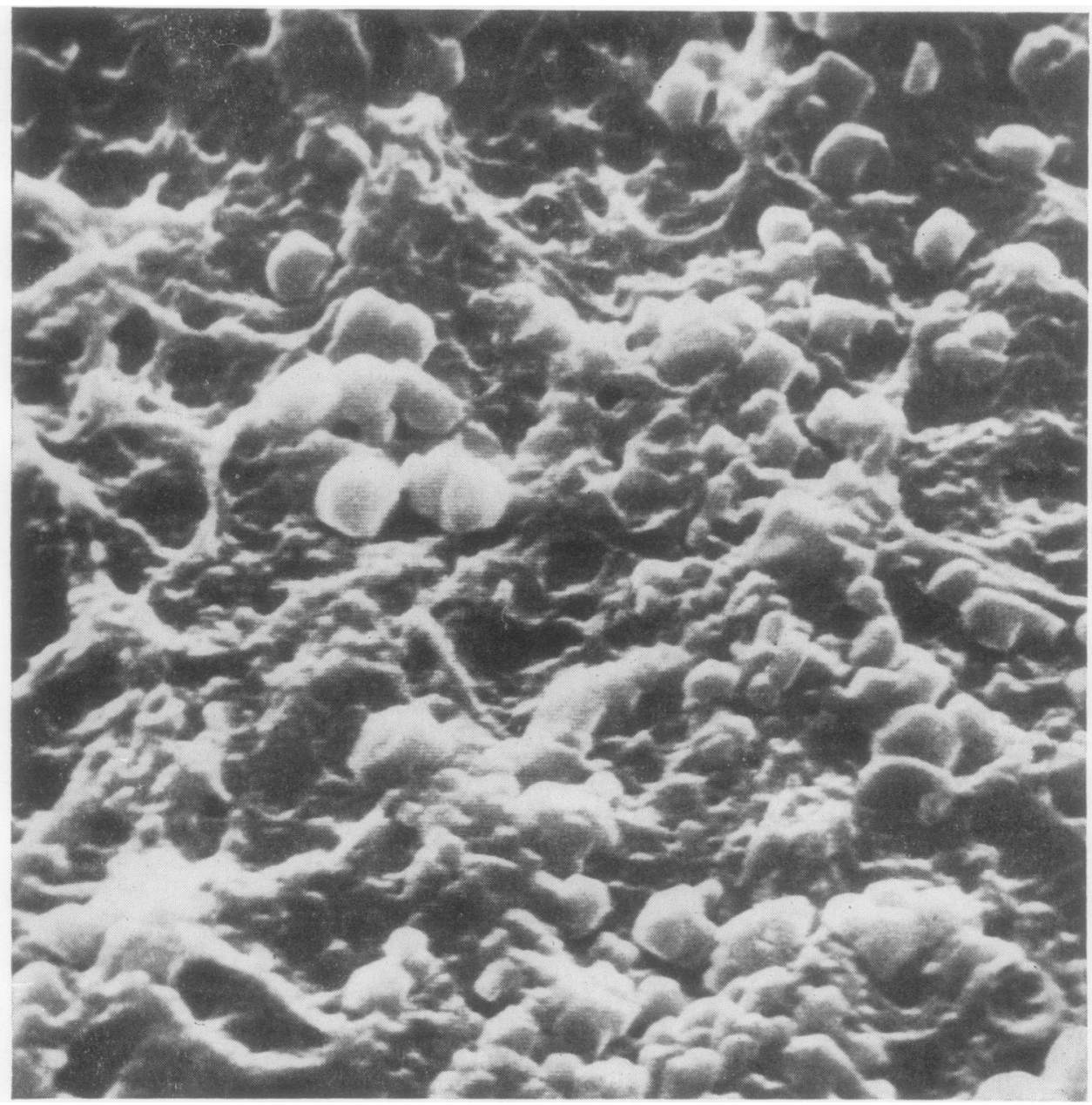

Fig. 3.-Synovial fluid, fixed in osmium tetroxide. $\times 5,200$. 
Furthermore, their diameter corresponded roughly to the height of the surface roughnesses. These observations suggest that, for healthy cartilage where the surface is gently undulating, the ridges contain the large collagen bundles and the depressions the networks of small bundles, the whole system being held together and smoothed by ground substance. The furry feel of older cartilage surfaces noted by Meyer (1931) is doubtless due to these larger bundles becoming partially detached from the underlying surface.

\section{(2) Synovial Fluid}

The appearance of synovial fluid depended upon the method of preparation. Considering the simplest method first of all, where droplets of synovial fluid from normal knee joints were placed on to glass and allowed to dry in air, it was found that cross-shaped structures had precipitated in a background substance (Fig. 2, p. 3). Examination of individual cross-shaped units showed that they were compounded of small aggregates of rather indefinite morphology but of typical individual size $-4 \mu \mathrm{m}$. The width of the branches of the crosses was typically $25 \mu \mathrm{m}$. Because of the dimensions of the individual complex molecules in solution (Ogston and Stanier, 1951) and their concentration in synovial fluid, it can be deduced that there will be a good deal of interaction and intertanglement, so the cross shapes probably represent intertangled agglomerations of complex molecules.

When specimens of synovial fluid were prepared by osmium tetroxide fixation, their appearance was variable but had two distinct morphological features.
The first consisted of discrete particles which were roughly spherical, and the second a "stringy" network. Both these phases are shown in Fig. 3 (opposite).

A histogram (Fig. 4) has been drawn showing the distribution of sizes of the spherical shapes. The results for this histogram were taken from Fig. 3 and from other micrographs of different specimens. Diameters up to $1 \mu \mathrm{m}$. only are recorded because beyond that size individual particles lost their distinct morphological appearance.

It has already been pointed out that the concentration of molecules of acid-protein complex in synovial fluid is such that they will be largely intertangled with one another so that the network, which covers most of Fig. 3, would be expected to be more representative of the bulk structure of synovial fluid. In very dilute solutions of complex, however, the molecules probably take on a roughly spherical configuration, with a diameter estimated at about $0.3 \mu \mathrm{m}$. by Ogston and Stanier (1951). When osmium tetroxide solution is added to the drop of synovial fluid, conditions at the interface between the solutions would reproduce this dilute concentration and hence single molecules or small aggregates might well remain on the surface of the bulk of the synovial fluid on subsequent dehydration. There was still the possibility that they represented contaminant material derived from the fixing or drying solutions, but in Fig. 5 the appearance of freeze-dried synovial fluid is shown and this too has a similar sort of structure, namely a network with spherical shapes distributed amongst it. With freeze-drying preparation, there would not be expec-

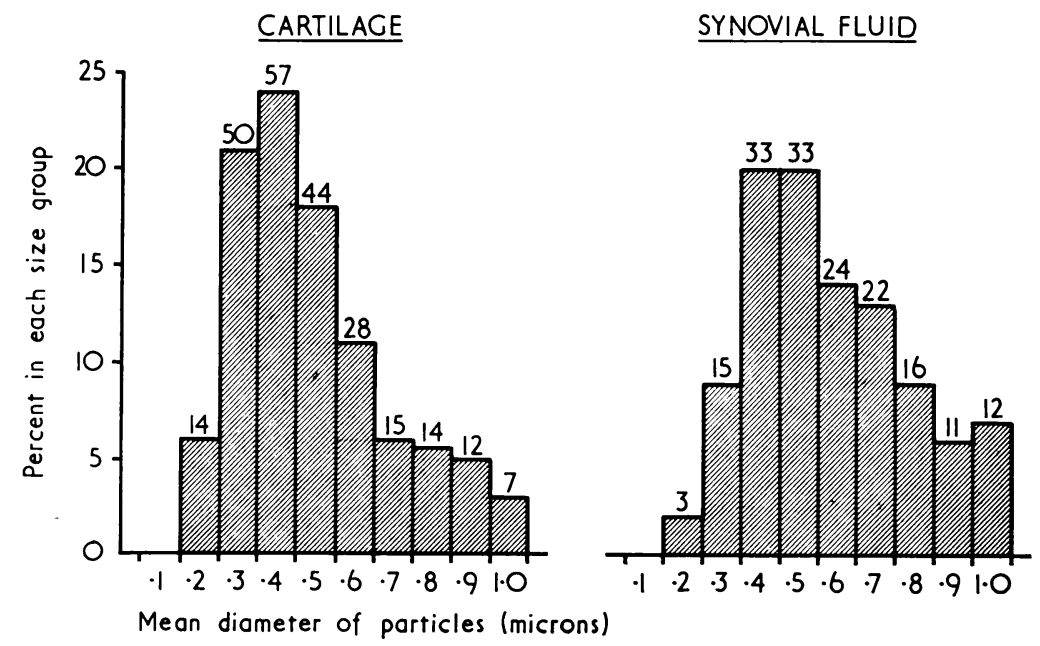

Fig. 4.-Distribution of sizes of particles on surfaces of cartilage and on specimens of synovial fluid. 


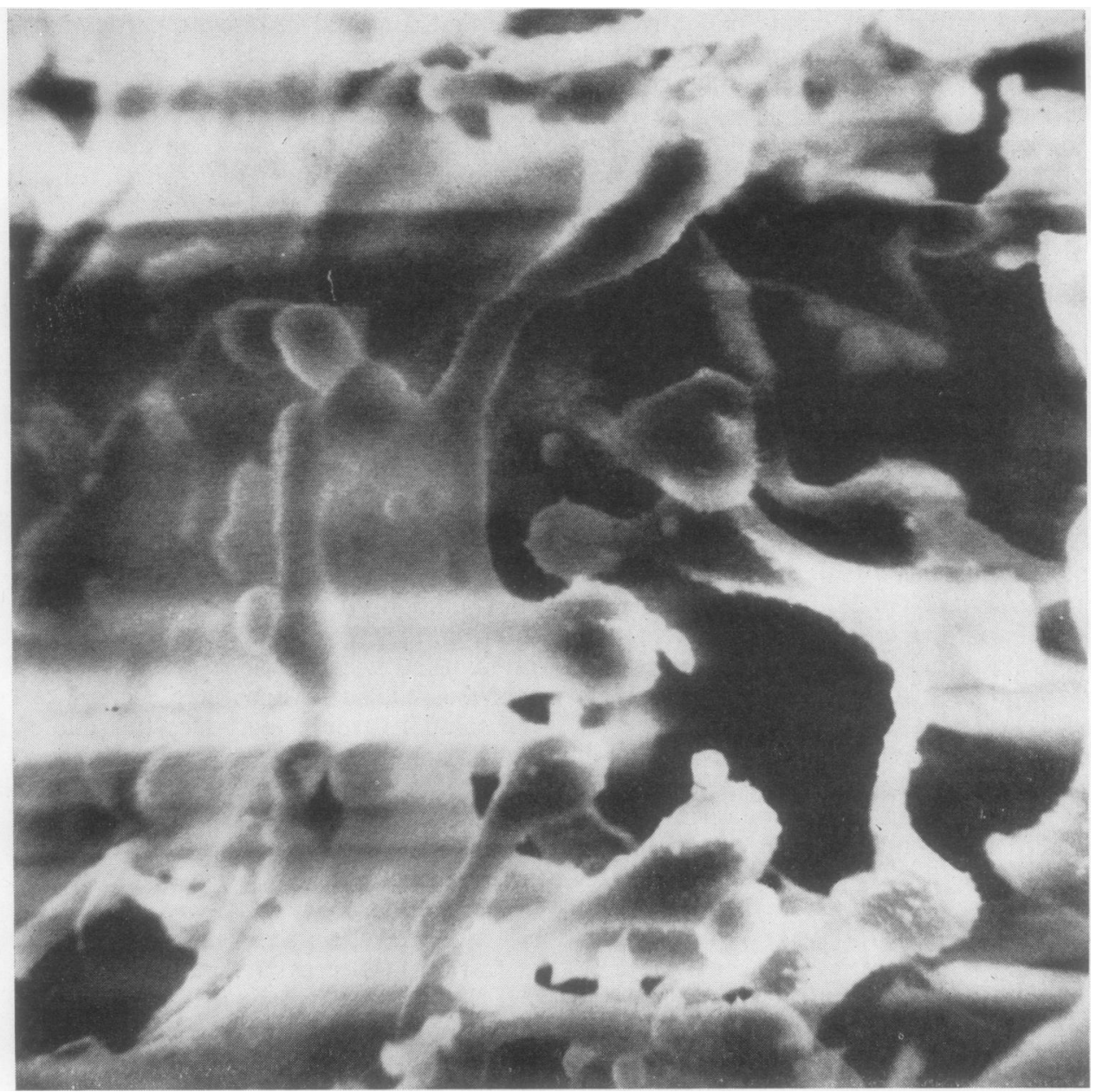

Fig. 5. - Synovial fluid, freeze dried. $\times 1,600$.

ted to be so many discrete particles because there is no question of a dilute solution at the surface. Indeed, over large areas of the surface of freezedried fluid, no spherical shapes could be seen but there were nonetheless some areas where they abounded in greater concentration than in Fig. 5 .

Comparison of Fig. 2 with Fig. 3 and 5 leads to the conclusion that the fixation process, whether by osmium tetroxide or by freeze drying, prevents the collapse of the chain structure of the acidprotein complex molecules and preserves the overall structure much as it is in the bulk solution of synovial fluid. It is easy to visualize why the fluid behaves as a viscous compression resistant gel, with such a tangled form and how water held within it can be taken up or exuded.
(3) Cartilage Surfaces and the Formation of Trapped Pools

In order to detect the appearance of synovial fluid on the surfaces of cartilage, specimens were prepared in different ways. One cartilage specimen, for example, was smeared with synovial fluid and fixed in that condition without wiping the surface at all. The microscope revealed clumps of deposit on the surface appearing to be aggregates of molecules of complex rather than a complete network. Once again, however, the osmium-fixing solution will have diluted the fluid on the cartilage surface. Other specimens which were wiped with a tissue moistened with distilled water showed only a sparse deposit, or even no deposit at all. The deposits 


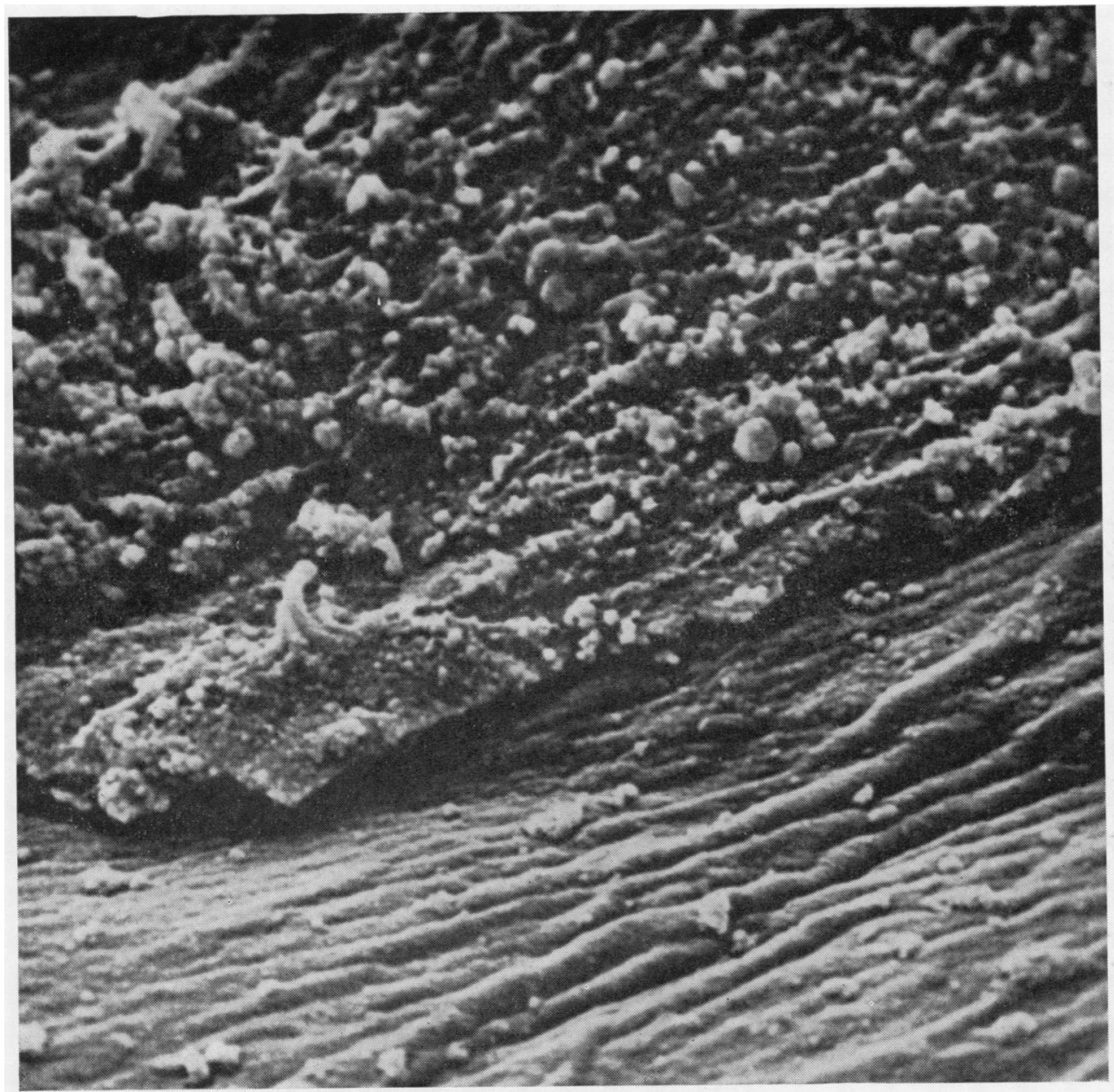

Fig. 6. Cartilage surface showing a non-random distribution of surface deposit. $\times 1,660$.

were usually spherical shapes, but in some cases they were long chains sprawled over the surface.

An interesting observation was that the spheres were not distributed randomly over the cartilage surface but seemed to congregate firstly on the undamaged surface layer of the cartilage as a whole, and secondly on the large collagen fibre bundles on the surface. The first of these cases is illustrated in Fig. 6, showing a specimen where the top skin had been partially peeled away but where the whole surface was uniformly soaked with synovial fluid and gently wiped with a moist tissue before fixation. Fig. 7 shows spherical particles clustered around the large fibre bundles. This cartilage specimen was from a joint with mild osteoarthrosis.
To correlate particle sizes of deposits on cartilage, with the particles observed in synovial fluid specimens alone, histograms were drawn from several cartilage specimens, including those shown in Fig. 6 and in Fig. 7 (overleaf).

The histograms between different specimens were very similar and combining all the figures led to the histogram shown in Fig. 4. Again, particles up to $1 \mu \mathrm{m}$. only in diameter are considered.

It has been mentioned in the introduction that measurements have been made of cartilage surface which showed that a typical surface contained undulations about $2.5 \mu \mathrm{m}$. deep spaced about $25 \mu \mathrm{m}$. apart. In older cartilage, these tended to be superimposed upon larger undulations of about 10 


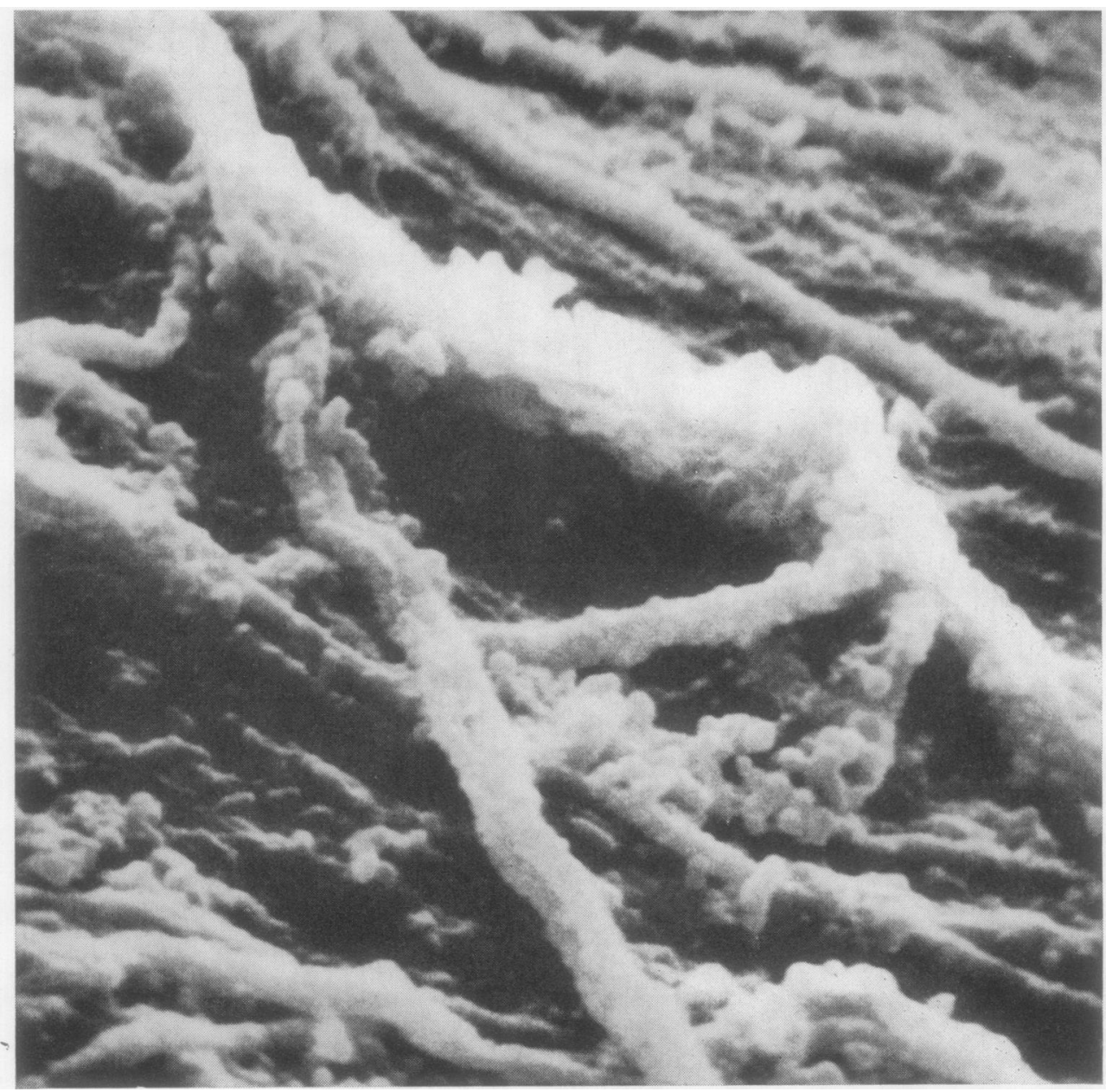

Fig. 7.-Clustering of spherical particles around large surface fibre bundles. $\times 4,800$.

times the magnitude. The undulations can be clearly seen in Fig. 8 (opposite). Because cartilage deforms significantly under the pressures imposed upon it in a living joint, it would be expected that, when one cartilage surface is pressed against another or against glass, an array of cavities would be formed, of variable shape and with many cavities interlinking.

Fig. 9 (overleaf) shows a typical appearance of cartilage which had been compressed against glass with synovial fluid interposed and fixed in that condition with osmium tetroxide. The loading pressure was about $7 \mathrm{~kg} . / \mathrm{cm}^{2}{ }^{2}\left(100 \mathrm{lb} . / \mathrm{in} .{ }^{2}\right)$ and the estimated time before appreciable hardening of cartilage took place during fixation was 4 hours. It seems fairly clear that the dark areas on the photo-o graph are cartilage which has been in boundary contact with the glass, whilst the light areas haveo been depressions in the cartilage which have retained trapped pools of synovial fluid. A histogram of the sizes of the particles within the trapped pools N correlated well with that of synovial fluid specimens (Fig. 4), but there is a strong likelihood that, whereas $\sigma$ the deposit in the trapped pools would be principally derived from synovial fluid, it would also contain osmium salts, together with other substances which $\stackrel{\mathbb{D}}{\rightarrow}$ may have been dissolved in the fixing solution.

The second example of the formation of trapped 0 pools (Fig. 10, overleaf) was taken of a specimen pre- $-\overrightarrow{\mathbb{D}}$ pared by freeze drying, using cartilage compressed $\frac{\mathbb{\Phi}}{Q}$ 


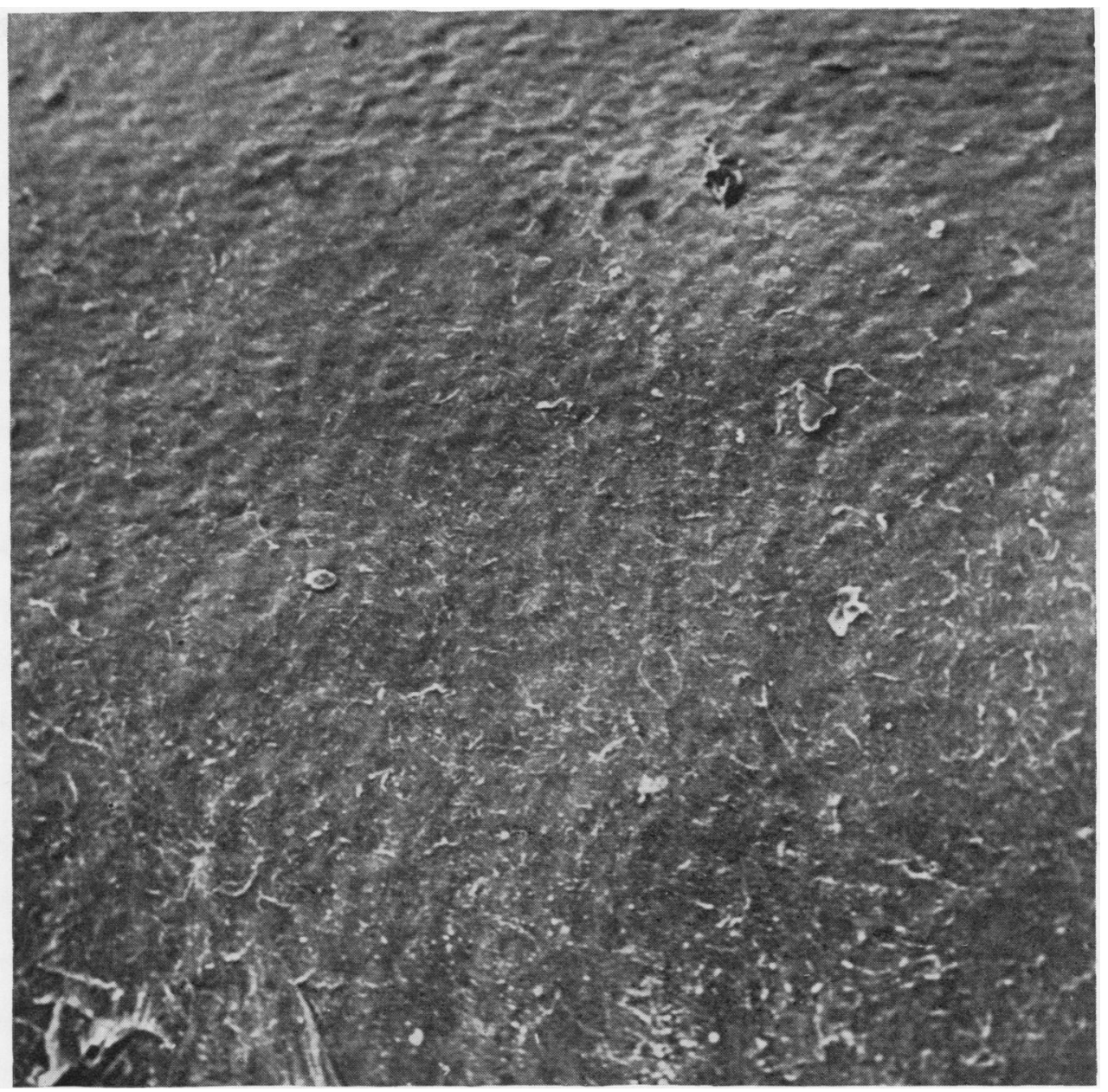

Fig. 8.-Undulations on surface of normal cartilage. $\times 54$.

against cartilage with fluid interposed. The contact pressure here was about $14 \mathrm{~kg} . / \mathrm{cm} .{ }^{2}\left(200 \mathrm{lb}\right.$. $/$ in. $\left.^{2}\right)$ and in this case fixation by immersion in liquid nitrogen was carried out 2 minutes after the application of the load. The appearance of the deposit on the cartilage surface is strikingly different from that in the osmium-fixed specimen, which probably reflects the dilution of synovial fluids by osmium tetroxide solution in the first case, the relative times of fixation, and the inherently different physical and chemical characteristics of fixation. Nonetheless the similarities are that there are localized areas of synovial fluid in each case, showing that trapped pools were formed.

\section{Cartilage and Fluid from Diseased Joints}

Some surface degeneration of the cartilage attributable to sliding damage seems to be present to some degree in all old load-bearing synovial joints. It is when this damage becomes severe and other features of the whole joint are affected that osteoarthrosis occurs, but mild cartilage degeneration is the first obvious manifestation. Fig. 11 (p. 12) depicts an area of cartilage displaying this sliding damage and there are several features of particular note.

(i) The larger type of fibre bundles mentioned earlier can be clearly seen, their distribution over 


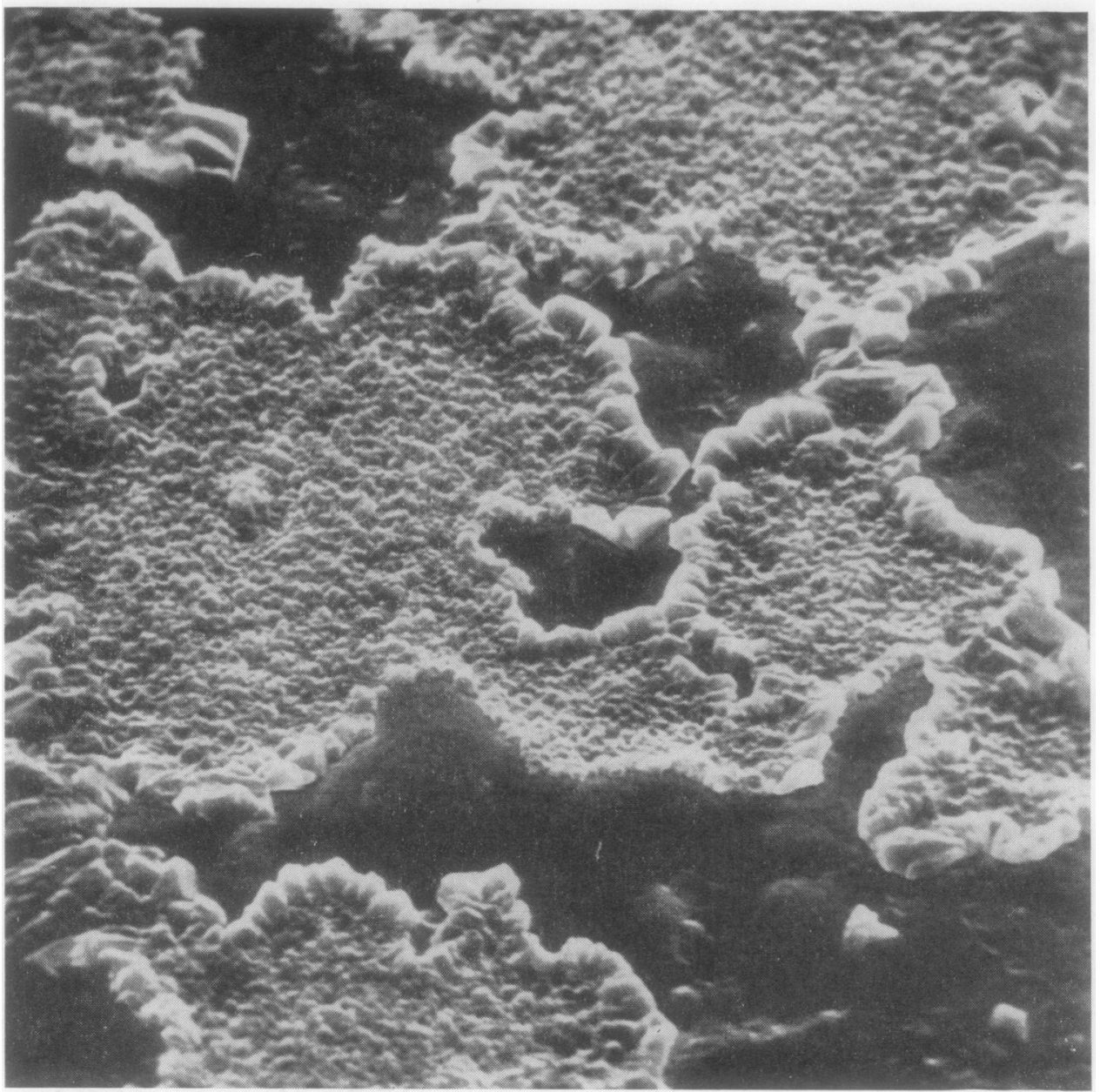

Fig. 9. - "Trapped pools" formed between cartilage and glass, fixed in osmium tetroxide. $\times 1,460$.

the surface correlating well with the spacing of the undulations, namely at a pitch of about $25 \mu \mathrm{m}$. Another feature is the good evidence of a definite surface layer. Moreover, this layer appears to have become broken up in some areas and detached from the underlying cartilage in others. The process probably starts when the anchoring fibres of the large fibre bundles become torn partly through repeated stressing and partly through the wearing away of the ground substance. However, the ground substance around the small fibres in between the large ones seems to be well preserved in some parts. (ii) Another common disease of cartilage is chondromalacia, which has been shown to afflict areas of non weight-bearing cartilage (Goodfellow and Bullough, 1967). Fig. 12 (p. 13) shows an example believed to be of this type. Here, the ground 0 substance seems to be breaking up rather than the ${ }^{\omega}$ fibres, and it is likely that the furry deposit represents breakdown products of the ground substance. The remaining cartilage structure is seen to be "open", a characteristic of chondromalacia.

(iii) Some synovial fluid from a rheumatoid joint $\frac{0}{0}$ was fixed in osmium tetroxide and examined. The whole mass was composed of spherical shapes, a 


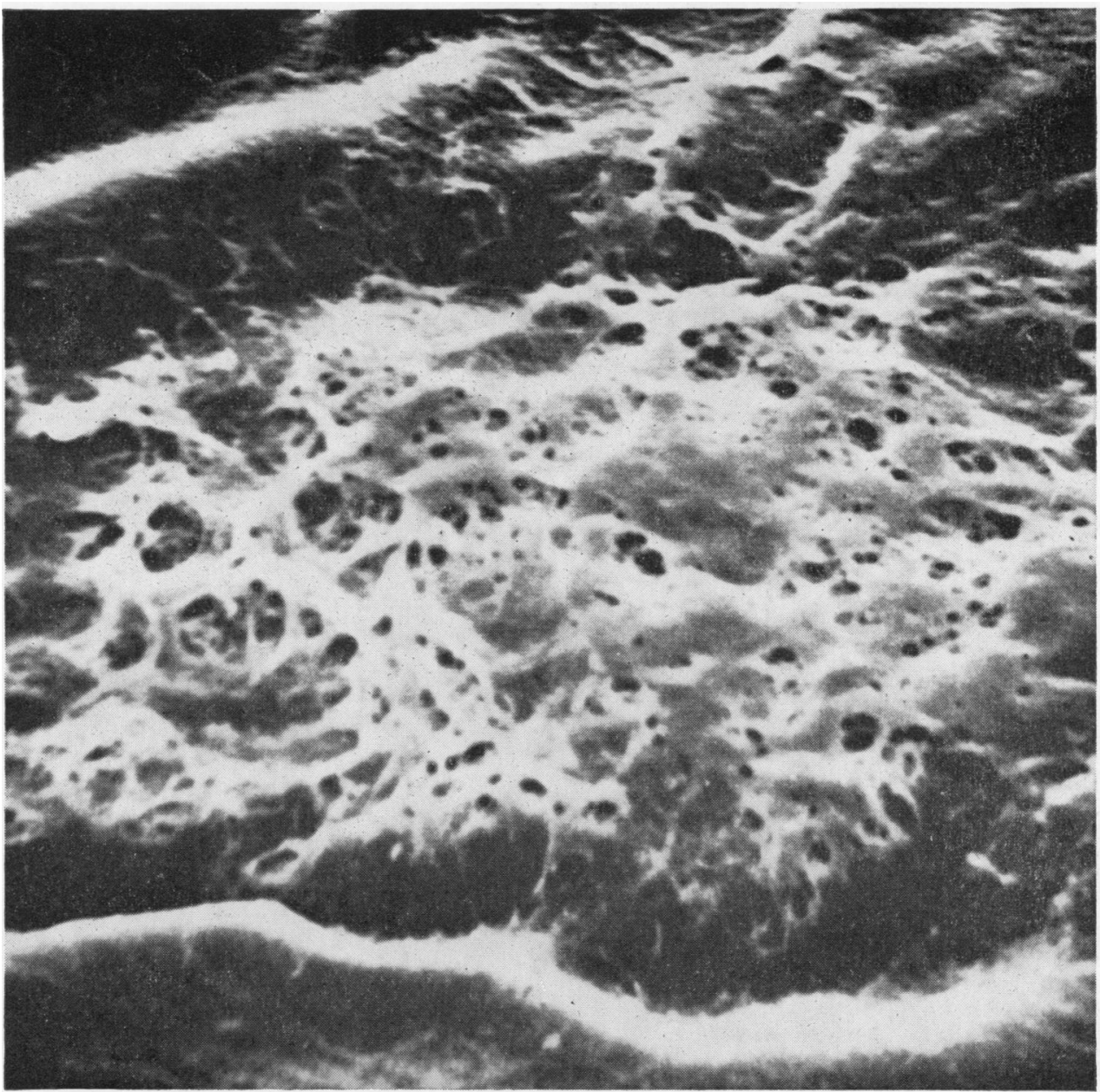

Fig. 10.-A "trapped pool" formed between cartilage and glass, freeze dried. $\times 4,500$.

histogram of sizes showing that the vast majority of diameters lay in the range $0 \cdot 2-0 \cdot 4 \mu \mathrm{m}$. The indications were, therefore, that the hyaluronic acidprotein complex molecules were separate or in aggregates of only a few molecules, and that there was far less interlinking between neighbouring molecules than in healthy synovial fluid. This would be partly due to the dilution of complex molecules in the bulk synovial fluid.

\section{Conclusions}

(1) The surface of cartilage is made up of a layer about $3 \mu \mathrm{m}$. thick consisting of bundles of collagen fibres embedded in a ground substance.
(2) The surface fibre bundles are of two distinct sizes, the larger being $1-3 \mu \mathrm{m}$. diameter spaced about $25 \mu \mathrm{m}$. apart in random directions.

(3) Synovial fluid, when fixed and dried, presented a tangled network structure, probably consisting primarily of acid-protein complex.

(4) Spherically-shaped particles have been noted in both the fluid and on cartilage surfaces; their size indicated that they were aggregates of complex molecules, the smallest particles being consistent with their being acid-protein complex of spherical configuration of diameter $0 \cdot 2 \mu \mathrm{m}$. 


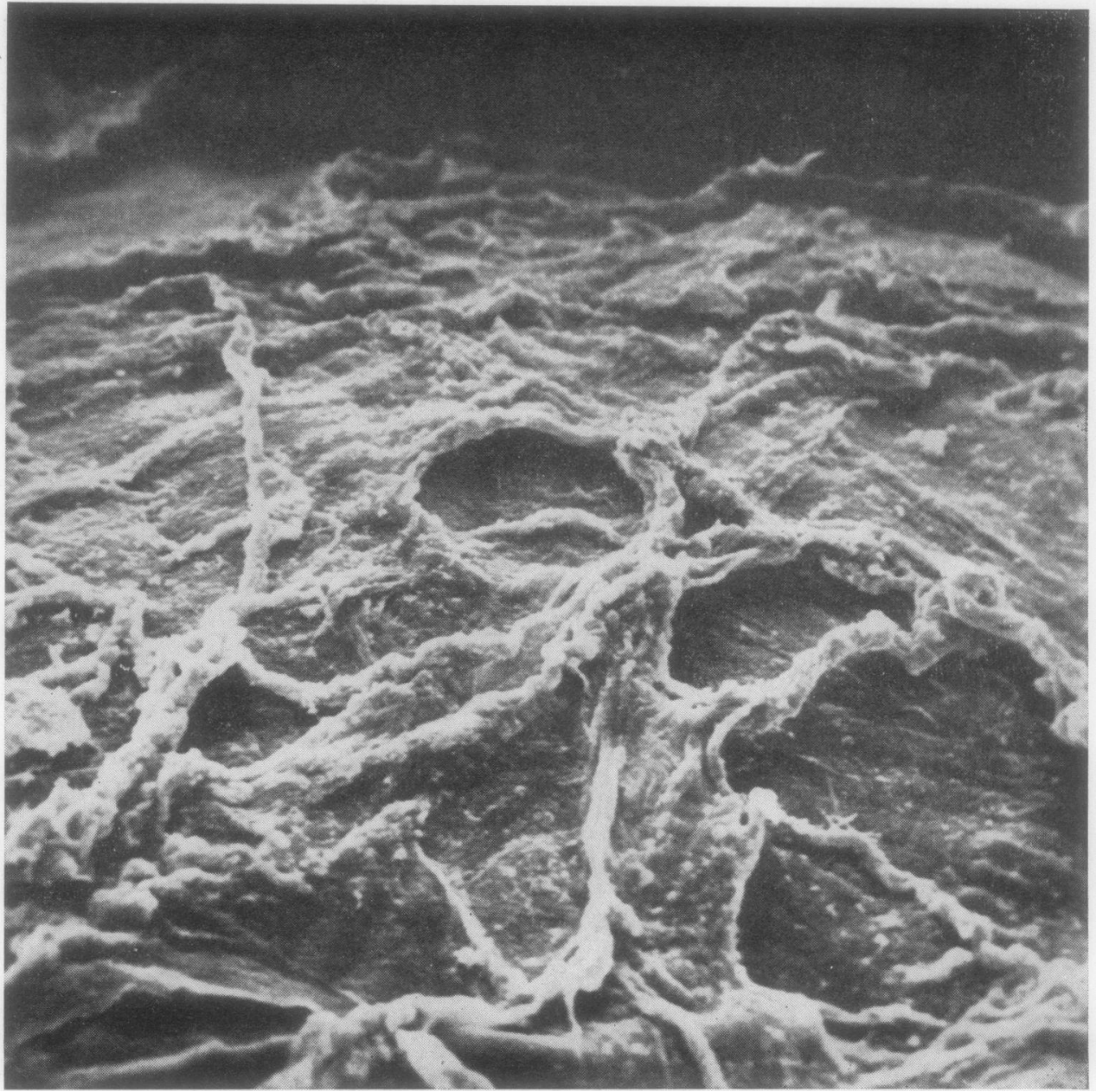

Fig. 11.-Cartilage surface, showing damage due to sliding. $\quad \times \mathbf{4 8 0}$.

(5) These particles seemed to congregate preferentially on undamaged rather than on damaged cartilage surface and on large collagen fibre bundles.

(6) The surface of cartilage is gently undulating, the peak-to-valley height of the roughnesses being about $2 \cdot 5 \mu \mathrm{m}$. and the pitch $25 \mu \mathrm{m}$.

(7) When cartilage was compressed on to a glass surface or on to cartilage, trapped pools of synovial fluid were formed. Areas around the pools did not appear to be protected by hyaluronic acid-protein complex.
(8) Damage due to sliding between cartilageo surfaces seems to take place by large fibre bundles becoming loosened and tearing off areas of surfaceos skin.

(9) In chondromalacia, the ground substance apparently degenerates leaving breakdown deposits on the cartilage surface.

Mortuary specimens were kindly supplied by Mr. V. F A. Tide and Mr. A. Compton of Leeds General Infirmary. The Group is in receipt of grants from the Arthritis ando Rheumatism Council and The West Riding Medicald Trust. 


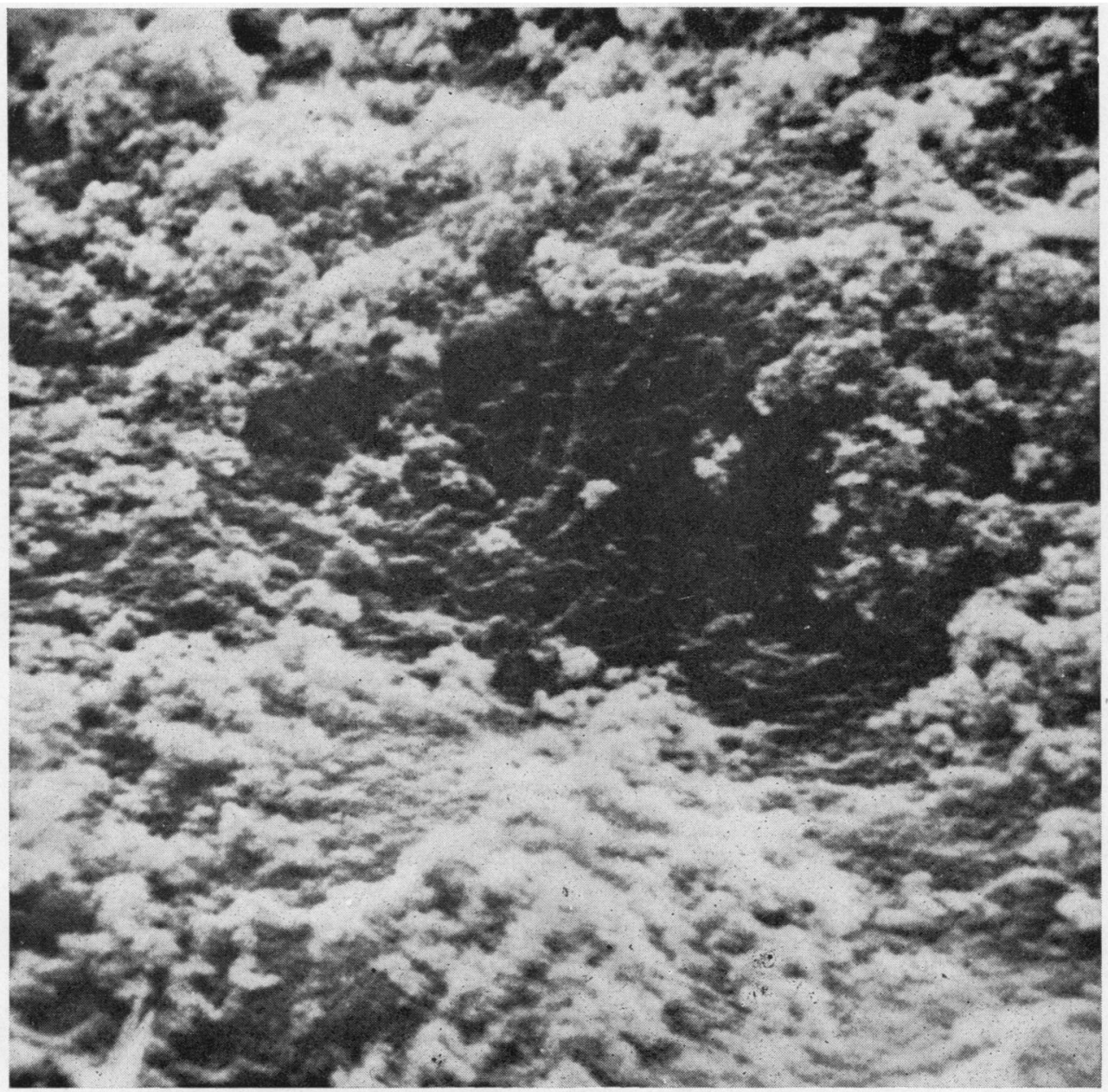

Fig. 12.-Degenerate cartilage surface, probably chondromalacial. $\times 4,800$.

\section{REFERENCES}

Benninghoff, A. (1930). Morph. Jb., 65, 11 (Über Leitsysteme der Knochenkompakta. Studien zur Architektur der Kochen. III Teile).

Davies, D. V. (1966). Fed. Proc., 25, 1069 (Synovial fluid as a lubricant).

Dowson, D., Longfield, M. D., Walker, P. S., and Wright, V. (1969). "An Investigation of the Friction and Lubrication in Human Joints", in "Tribology Convention, 1968, Pitlochry". Proc. Inst. mech. Eng., 182, Pt. 3N. In the press.

Goodfellow, J. W., and Bullough, P. G. (1967). J. Bone Jt Surg., 49-B, 175 (The pattern of ageing of the articular cartilage of the elbow joint).

Little, K., Pimm, L. H., and Trueta, J. (1958). Ibid., 40-B, 123 (Osteoarthritis of the hip. An electron microscope study).

Maroudas, A. (1967). "Hyaluronic Acid Films", in "Lubrication and Wear in Living and Artificial Human Joints: A Symposium". Proc. Inst. mech. Eng., 181, Pt. 3J, p. 122. 
Martin, A. V. W. (1953). "Fine Structure of Cartilage Matrix", in "Nature and Structure of Collagen", ed. J. T. Randall and S. F. Jackson, pp. 129-139. Butterworth, London.

Meyer, A. W. (1931). J. Bone Jt Surg., 13, 341 (The minuter anatomy of attrition lesions).

Negami, S. (1964). "The Dynamic and Mechanical Properties of Synovial Fluid". M.Sc. Thesis, Lehigh University, Bethlehem.

Ogston, A. G., and Stanier, J. E. (1951). Biochem. J., 49, 585 (The dimensions of the particle of hyaluronic acid complex in synovial fluid).

Ropes, M. W., and Bauer, W. (1953). "Synovial Fluid Changes in Joint Disease”. Harvard Univ. Press, Cambridge, Mass.

Tolansky, S. (1954). Vacuum, 4, 456 (Perfection of contour by vacuum deposited thin films).

Walker, P. S., Dowson, D., Longfield, M. D., and Wright, V. (1968). Ann. rheum. Dis., 27, 512 (Boosted lubrication in synovial joints by fluid entrapment and enrichment).

Le comportement du liquide synovial sur la surface du cartilage articulaire

\section{RÉSUMÉ}

(1) La surface du cartilage est faite d'une couche d'à peu près $3 \mu \mathrm{m}$. de faisceaux de fibres de collagène enfouis dans la matrice.

(2) Les faisceaux de fibres à la surface sont de deux grosseurs distinctes, les plus gros étant de 1 à $3 \mu \mathrm{m}$. de diamètre espacés d'à peu près $25 \mu \mathrm{m}$. et placés dans toutes les directions.

(3) Le liquide synovial, quand il est fixé et séché, a presenté une structure formée d'un réseau embrouillé, composé probablement d'un complexe acide-protéine principalement.

(4) Des particules de formes sphériques ont été notées dans le liquide ainsi que sur les surfaces du cartilage; leur dimension indiquait qu'ils étaient des agrégats de molécules complexes, la formation des plus petites particules étant compatible avec un complexe d'acideprotéine de configuration sphérique d'un diamètre de $0,2 \mu \mathrm{m}$.

(5) Ces particules semblaient se réunir de préférence sur un cartilage intact plutôt que sur une surface endommagée et sur les larges faisceaux des fibres de collagène.

(6) La surface du cartilage est légèrement ondulée, l'amplitude de rugosité étant d'à peu près $2,5 \mu \mathrm{m}$. et l'espacement de $25 \mu \mathrm{m}$.

(7) Quand le cartilage est comprimé sur une surface de verre ou sur du cartilage, des flaques circonscrites de liquide synovial sont formées. L'espace autour des flaques ne semblait pas être protégé par le complexe protéique d'acide hyaluronique.

(8) Les dommages causés par le glissement des surfaces du cartilage semblent avoir lieu par les larges faisceaux qui deviennent lâches et déchirent des parties de la surface externe.

(9) Dans la chondromalacie, la matrice apparemment dégénère laissant des dépôts de décor..position sur la surface du cartilage.
Comportamiento del líquido sinovial en las superficies del cartílago articular

\section{Sumario}

(1) La superficie del cartílago está formada de una capa de aproximadamente $3 \mu \mathrm{m}$. de espesor, compuesta de haces de fibras de colágeno enterradas en la matriz.

(2) Los haces de fibras de la superficie son de dos grosores, siendo los más grandes de 1-3 $\mu \mathrm{m}$. de diámetro, colocados a unos $25 \mu \mathrm{m}$. de distancia unos de otros en todas direcciones.

(3) El líquido sinovial, una vez fijado y secado, presentaba una estructura formada por una red compleja, compuesta probablemente de un complejo de ácidozo proteina principalmente.

(4) Se han notado partículas de forma esférica tanto en el líquido como en las superficies del cartílago; su tamaño indicaba que eran agregados de moléculas complejas, siendo la formación de pequeñas partículas compatible con un complejo de ácido proteina de configuración esférica, de un diámetro de $0,2 \mu \mathrm{m}$.

(5) Parecería que estas partículas se congregaran preferentemente en las superficies de los cartílagos no dañados y sobre los haces grandes de las fibras de colágeno.

(6) La superficie del cartílago es ligeramente ondulada, siendo la altura de las rugosidades de aproximadamente $2,5 \mu \mathrm{m}$. y el espacio entre ellas de $25 \mu \mathrm{m}$.

(7) Cuando el cartílago se comprimió contra una superficie de vidrio o contra cartílago, se formaron estancamientos de líquido sinovial. Las zonas alrededor de los estancamientos no parecían estar protegidas por complejos proteicos de ácido hialurónico.

(8) Los daños causados por deslizamiento entre superficies de cartílagos parecen ocurrir al aflojarse los grandes haces de fibras, que arrancan partes de la superficie externa.

(9) En la condromalacia, la matriz aparentemente degenera, dejando depósitos de descomposición en la superficie del cartílago. 